\title{
Role of antioxidative enzymes in toxic bloom forming Cyanobacteria
}

\author{
Archana Tiwari ${ }^{1 *}$ and Anjana Pandey \\ Nanotechnology and Molecular Biology Laboratory, Centre of Biotechnology, University of Allahabad, Allahabad - \\ 211002, INDIA \\ ${ }^{1}$ Present Address: Department of Biotechnology, Guru Nanak Girls College, Ludhiana (Pb), INDIA \\ *Corresponding author. E-mail: panarchana@gmail.com \\ Received: J uly 20, 2012; Revised received: J uly 27, 2012; Accepted: September 20, 2012
}

Abstract: The antioxidative enzymes catalase and ascorbate peroxidase in toxic bloom forming cyanobacteria play a pioneer role in scavenging free radicals, which are generated as an outcome of photosynthesis and respiration. Ten Bloom forming toxic cyanobacterial strains Synechococcus elongates, Synechocystis aquatalis, Merismopedia glauca, Microcystis aeruginosa, M. aeruginosa (O), Arthrospira (=S pirulina) platensis, Nostoc paludosum, Anabaena iyengarii, $A$. variabilis and Cylindrospermum muscicola were isolated from natural blooms and purified. The results depict the significant activity of antioxidative enzymes. In A. platensis the activity of catalase $(28.7 \pm 2.3 \mathrm{mM} /$ $\mathrm{min} / \mathrm{g}$ protein), and Ascorbate peroxidase $(1.91 \pm 0.12 \mathrm{mM} / \mathrm{min} / \mathrm{g}$ protein) enzyme was maximum. It was also observed that the activity of ascorbate perooxidase was very less compared to activity of catalase. The growth analysis and pigment profile were also studied. Growth measurements revealed that cells attain maximum growth nearly after 15-20 days of inoculation except $\mathrm{S}$. aquatalis, A. platensis and $\mathrm{N}$. paludosum maximum, where optimum growth was achieved after $25^{\text {th }}$ day. Chlorophyll-a content of A. platensis showed maximum concentration (14.47 \pm $1.17 \mathrm{mg} / \mathrm{L})$ and minimum concentration in $\mathrm{S}$. elongates $(2.30 \pm 0.138 \mathrm{mg} / \mathrm{L})$. The concentration of phycobiliproteins was found maximum in A. platensis $(2.09 \mathrm{mg} / \mathrm{ml})$. The detection of antioxidative potential of cyanobacterial strains will help to broaden the knowledge about their survival and can pave path for their utilization in biotechnology.

Keywords: Antioxidative enzymes, Ascorbate peroxidase, Catalase, Cyanobacteria, Toxic Blooms

\section{INTRODUCTION}

Cyanobacteria are photosynthetic prokaryotes. They possess very simple cellular structure. The photosynthetic apparatus is represented by isolated and freely lying photosynthetic lamellae. Chlorophyll a and several accessory pigments (phycoerythrin and phycocyanin) are embedded in these photosynthetic lamellae. The major photosynthetic pigment in cyanobacteria is Chlorophyll a. The outer surface of thalakoids of cyanobacteria contains phycobilisomes, which are light harvesting clusters of phycobiliproteins. The phycobilisome components (phycobilin) are responsible for the bluegreen pigmentation of most cyanobacteria. They absorb light in the visible region and transfer the excitation energy to Chl-a molecule. Phycobiliproteins are major photosynthetic accessory pigments of cyanobacteria (Minu et al., 2011).

The toxins secreted by cyanobacteria can be hepatotoxic, neurotoxic, cytotoxic or dermatotoxic in their mode of action. The exploration of antioxidative potential of these bloom forming toxic cyanobacteria is of immense importance. Reactive oxygen species are generated because of aerobic respiration and oxygenic photosynthesis. The active oxygen species are capable of damaging membranes, proteins, pigments and genetic material, disrupting the metabolism of the organism (Shaaltiel and Gressel, 1986, Scandalios, 1993). Cyanobacteria and plants have developed a number of antioxidative systems for management of free radicals. Early reports indicated the presence of two major hydrogen peroxide scavenging activities in cyanobacteria, catalase and ascorbate peroxidase (TelOr et al., 1985, 1986).

Catalase activity has been found in all cyanobacteria species (Miyake et. al., 1991). Catalase (EC 1.11.1.6) is an extraordinary enzyme as the reaction it catalyses is crucial to life. It catalyses conversion of hydrogen peroxide, a powerful and potentially harmful oxidizing agent to water and molecular oxygen (Sichak and Dounce, 1986; Halliwell and Gutteridge, 1999). These enzymes also use hydrogen peroxide to oxidize toxins including phenols, formic acid, formaldehyde, ethanol, methanol or elemental mercury. Catalases have four heme containing subunits, which are responsible for carrying out catalase's activity (Fita and Rossmann, 1985; Darr and Fridovich, 1986).

Ascorbate peroxidase (APX) is a hydrogen-scavenging enzyme. It is a member of the heme peroxide family of enzymes, which are found in most life forms, higher plants, yeasts, algae and some cyanobacteria. They have many biological functions including antibacterial action, 
hormone synthesis and hydrogen peroxide removal. Ascorbate peroxidase (EC 1.11.1.11) exists as isozymes and plays important role in the metabolism of hydrogen peroxide. A lot of work on the purification, molecular cloning and physiological functions of APX isoenzymes has been reported (Nakano and Asada, 1981, Mittler and Zilinkas, 1994). This utilizes ascorbate as its electron donor to reduce hydrogen peroxide to water with the concomitant generation of monodehydroascorbate (MDAsA), a univalent oxidant of ascorbate. APX in combination with the effective AsA-GSH cycle functions to prevent the accumulation of toxic levels of hydrogen peroxide in photosynthetic organisms (Asada, 1992, 1997). The aim of the present study was to explore the antioxidative potential of catalase and ascorbate peroxidase in toxic bloom forming cyanobacteria.

\section{MATERIALS AND METHODS}

Ten cyanobacterial strains belonging to genera Synechococcus elongates, Synechocystis aquatalis, Merismopedia glauca, Microcystis aeruginosa, M. aeruginosa $(\mathrm{O})$, Arthrospira (=Spirulina) platensis, Nostoc paludosum, Anabaena iyengarii, A. variabilis

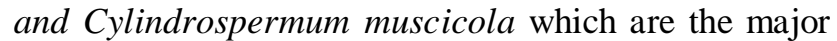
bloom forming forms in Northern India were taken for the study and were isolated from natural blooms (Rippka et al., 1979, Rippka, 1988). The strains were purified and enriched in the laboratory in BG-11 medium (Stanier et al., 1971).

Growth rate was measured by recording the absorbance at $660 \mathrm{~nm}$ from the day of inoculation, after every five days until 40 $0^{\text {th }}$ Day (Ohtake et al., 1989). Protein was extracted by suspending the cell pellet in $1 \mathrm{ml} 100 \mathrm{mM}$ phospate buffer ( $\mathrm{pH} 7.5)$ containing Lysozyme $(0.5 \mathrm{mg} /$ $\mathrm{ml}), \operatorname{EDTA}(5 \mathrm{mM}), \operatorname{PMSF}(1 \mathrm{mM}), \operatorname{PVP}(1 \%)$ and Triton $(0.1 \%)$. The mixture was incubated on ice for 30 minutes followed by centrifugation at $10,000 \mathrm{rpm}$ for 30 minutes at $4^{\circ} \mathrm{C}$ and supernatant stored at $-20^{\circ} \mathrm{C}$.

Protein concentration was determined using Bovine serum albumin as a standard (Bradford, 1976). The quantification of Chlororphyll-a was done in methanolic extracts by absorbance at $665 \mathrm{~nm}$ and $652 \mathrm{~nm}$ (Porra et al., 1989). Concentration of C-phycocyanin (PC), Cphycoerythrin (PE) and Allophycocyanin (APC) was calculated using the equations derived from extinction coefficients of purified phycobiliproteins (Bennett and Bogorad, 1971).

For extraction and determination of Catalase (EC 1.11.1.6), fresh cyanobacterial culture $(10 \mathrm{ml})$ was taken and centrifuged at $8,000 \mathrm{rpm}$ for 15 minutes at $4^{\circ} \mathrm{C}$ and the pellet was kept on ice. The pellet was homogenized with $100 \mathrm{mM}$ phosphate buffer (pH 7.0) containing $0.5 \mathrm{mg} / \mathrm{ml}$ Lysozyme, 5mM EDTA, 1 mM PMSF, $1 \%$ PVP and $0.1 \%$ Triton. Incubation was done on ice for 30 minutes followed by centrifugation at 10,000 rpm for 30 minutes at $4{ }^{\circ} \mathrm{C}$. Catalase activity was determined by monitoring the consumption of hydrogen peroxide at $240 \mathrm{~nm}$ for 5 minutes (Rao et al., 1996). For measurement of APX activity, $10 \mathrm{ml}$ of fresh culture was taken and centrifuged at 8,000 rpm for 15 minutes at $4^{\circ} \mathrm{C}$ and the pellet was homogenized in $100 \mathrm{mM}$ potassium phosphate buffer $(\mathrm{pH}$ 7.5) containing 5 mM EDTA, $1 \mathrm{mM}$ PMSF, $1 \%$ PVP $0.1 \%$ Triton and $5 \mathrm{mM}$ ascorbate. Incubation was done on ice for 30 minutes followed by centrifugation at $10,000 \mathrm{rpm}$ for 30 minutes at $4^{\circ} \mathrm{C}$. APX activity was determined by following the decrease in absorbance at $290 \mathrm{~nm}$ for $3 \mathrm{~min}$ (Nakano and Asada, 1981).

\section{RESULTS}

Growth of cyanobacterial cultures depends on the conditions like light, temperature, nutrients etc. In this, study growth measurements revealed that cells attain maximum growth nearly after 15-20 days of inoculation. But in S. aquatalis, A.platensis and N. paludosum maximum growth was achieved after $25^{\text {th }}$ day. After maximum growth, the cells begin to die due to excess of metabolites in the medium (Fig.1).

The protein content of $A$. iyengarii $(12.78 \pm 0.97 \mathrm{~g} / \mathrm{l})$ was found to be maximum followed by $A$. variabilis ( 6.41 $\pm 0.68 \mathrm{~g} / \mathrm{l})$, N. paludosum $(5.28 \pm 0.45 \mathrm{~g} / \mathrm{l}), \mathrm{C}$. (3.16 \pm $0.24 \mathrm{~g} / \mathrm{l})$, S. el ongates $(2.5 \pm 0.15 \mathrm{~g} / \mathrm{l}), \mathrm{M}$. glauca $(2.5$ $\pm 0.19 \mathrm{~g} / \mathrm{l}), \mathrm{M}$. aeruginosa $(2.3 \pm 0.11 \mathrm{~g} / \mathrm{l}), \mathrm{M}$. aeruginosa $(\mathrm{O})(1.3 \pm 0.08 \mathrm{~g} / \mathrm{l}), \mathrm{A}$. platensis $(2.2 \pm 0.26$ g/ l) and S. aquatalis (1.6 $\pm 0.13 \mathrm{~g} / \mathrm{l}$ ) (Fig. 2).

The quantification of Chlorophyll-a was done in methanolic extracts by recording absorbance at 665 and $652 \mathrm{~nm}$. In terms of chlorophyll-a content A. (=Spirulina) platensis showed maximum concentration $14.47 \pm 1.17$ $\mathrm{mg} / \mathrm{L}$ followed by $\mathrm{S}$. aquatalis $(12.82 \pm 1.54 \mathrm{mg} / \mathrm{L}), \mathrm{M}$. glauca $(12.31 \pm 1.10 \mathrm{mg} / \mathrm{L})$, A. iyengarii $(7.50 \pm 0.67 \mathrm{mg} /$ L), N. paludosum $(7.16 \pm 0.98 \mathrm{mg} / \mathrm{L})$, A. variabilis $(6.28 \pm$ $0.71 \mathrm{mg} / \mathrm{L}), C$. muscicola $(5.43 \pm 0.42 \mathrm{mg} / \mathrm{L}), \mathrm{M}$. aeruginosa $(6.2 \pm 0.65 \mathrm{mg} / \mathrm{L}), \mathrm{M}$. aeruginosa $(\mathrm{O})(5.48 \pm$ $0.59 \mathrm{mg} / \mathrm{L})$, and S. el ongates ( $2.30 \pm 0.138 \mathrm{mg} / \mathrm{L})$ (Fig.3). The concentration of phycobiliproteins was found maximum in A. (=Spirulina) platensis $(2.09 \mathrm{mg} / \mathrm{ml})$ followed by $\mathrm{S}$. aquatal is $(1.84 \mathrm{mg} / \mathrm{ml}), \mathrm{M}$. glauca $(0.904$ $\mathrm{mg} / \mathrm{ml}), A$. iyengarii $(0.738 \mathrm{mg} / \mathrm{ml}) \mathrm{N}$. paludosum $(0.714$ $\mathrm{mg} / \mathrm{ml})$, A. variabilis $(0.699 \mathrm{mg} / \mathrm{ml})$ C. muscicola $(0.641$ $\mathrm{mg} / \mathrm{ml})$, S. elongates $(0.588 \mathrm{mg} / \mathrm{ml}), \mathrm{M}$. aeruginosa $(0.517$ $\mathrm{mg} / \mathrm{ml})$, and $M$. aeruginosa $(\mathrm{O})(0.498 \mathrm{mg} / \mathrm{ml})$ (Fig. 4$)$.

The activity of antioxidative enzyme- catalase was found in all ten cultures studied. The enzymatic activity of catalase in S. elongates $(3.67 \pm 0.38 \mathrm{mM} / \mathrm{min} / \mathrm{g}$ protein), S. aquatalis (15.18 $\pm 1.5 \mathrm{mM} / \mathrm{min} / \mathrm{g}$ protein), M. glauca $(8.17 \pm 0.89 \mathrm{mM} / \mathrm{min} / \mathrm{g}$ protein), M . aeruginosa $(4.12 \pm$ $0.59 \mathrm{mM} / \mathrm{min} / \mathrm{g}$ protein), M . aeruginosa $(\mathrm{O})(3.76 \pm 0.44$ $\mathrm{mM} / \mathrm{min} / \mathrm{g}$ protein), A. platensis $(28.7 \pm 2.3 \mathrm{mM} / \mathrm{min} / \mathrm{g}$ 


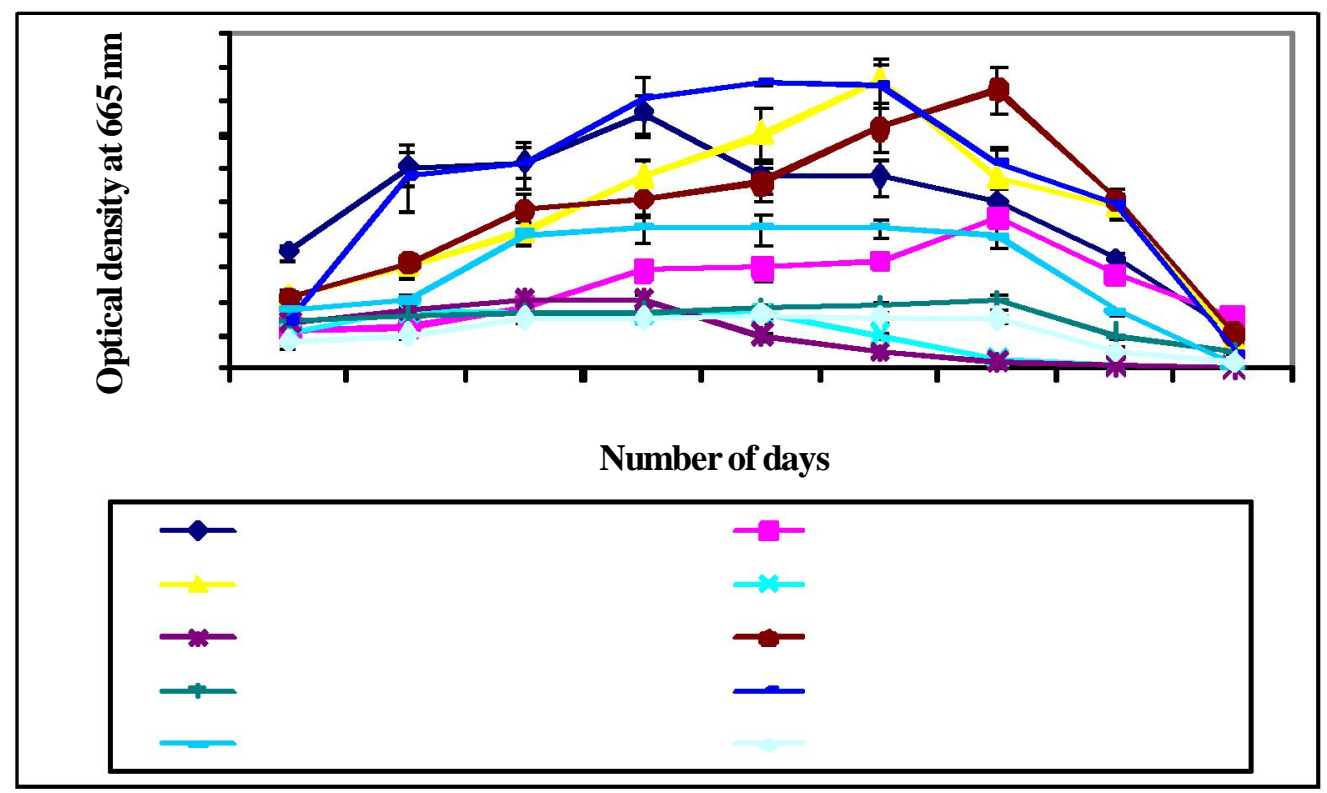

Fig.1. Growth curve of cyanobacteria.

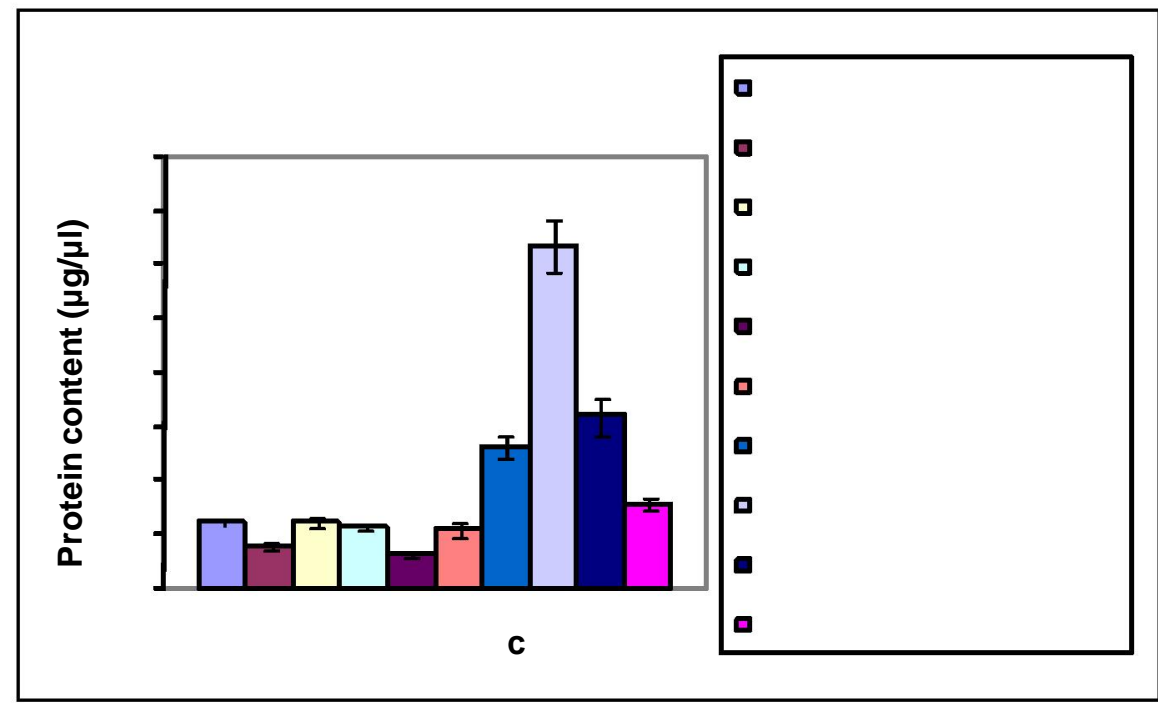

Fig.2. Protein concentration of cyanbacterial cultures.

protein), N. paludosum $(2.84 \pm 0.24 \mathrm{mM} / \mathrm{min} / \mathrm{g}$ protein), A. iyengarii $(4.89 \pm 0.23 \mathrm{mM} / \mathrm{min} / \mathrm{g}$ protein) $A$. variabilis $(4.36 \pm 0.55 \mathrm{mM} / \mathrm{min} / \mathrm{g}$ protein), C.muscicola (4.23 \pm $0.43 \mathrm{mM} / \mathrm{min} / \mathrm{g}$ protein) was observed (Fig.5).

Activity of ascorbate per oxidase: The activity of enzyme ascorbate peroxidase was lesser compared to the catalase activity. The ascorbate activity in S. elongates $(0.161 \pm$ $0.02 \mathrm{mM} / \mathrm{min} / \mathrm{g}$ protein), S. aquatalis $(0.9 \pm 0.06 \mathrm{mM} /$ $\mathrm{min} / \mathrm{g}$ protein $), \mathrm{M}$. glauca $(0.913 \pm 0.035 \mathrm{mM} / \mathrm{min} / \mathrm{g}$ protein), $M$. aeruginosa $(1.35 \pm 0.22 \mathrm{mM} / \mathrm{min} / \mathrm{g}$ protein), $M$. aeruginosa $(\mathrm{O})(0.440 \pm 0.03 \mathrm{mM} / \mathrm{min} / \mathrm{g}$ protein $), A$. platensis $(1.91 \pm 0.12 \mathrm{mM} / \mathrm{min} / \mathrm{g}$ protein), N. paludosum $(0.58 \pm 0.01 \mathrm{mM} / \mathrm{min} /$ ìg protein), $A$. iyengarii $(0.97 \pm 0$. $027 \mathrm{mM} / \mathrm{min} / \mathrm{g}$ protein) A. variabilis $(0.57 \pm 0.03 \mathrm{mM} /$ $\mathrm{min} / \mathrm{g}$ protein), C. muscicola $(0.388 \pm 0.05 \mathrm{mM} / \mathrm{min} / \mathrm{g}$ protein) was observed (Fig.6).

\section{DISCUSSION}

The toxicity of these bloom forming cyanobacteria has been confirmed by biochemical and molecular probes (Pandey, 2007).Our experimental analysis depicted that cyanobacterial strains vary in their growth parameters. The amount of pigments present in these cyanobacterial strains are sufficient for their utilization as therapeutic agents. Phycobilosomes consists upto $60 \%$ of the total soluble protein in cyanobacteria (Bennett and Bogorad 1973). The metabolism of phycobilisomes thus, has significant impact on the physiology of cyanobacteria. The antioxidant system is an important and necessary part of an organism's response to a changing environment. Our results showed the presence of antioxidative enzymes catalse and APX. Most environmental stresses appear to have an oxidative component. In the case of 


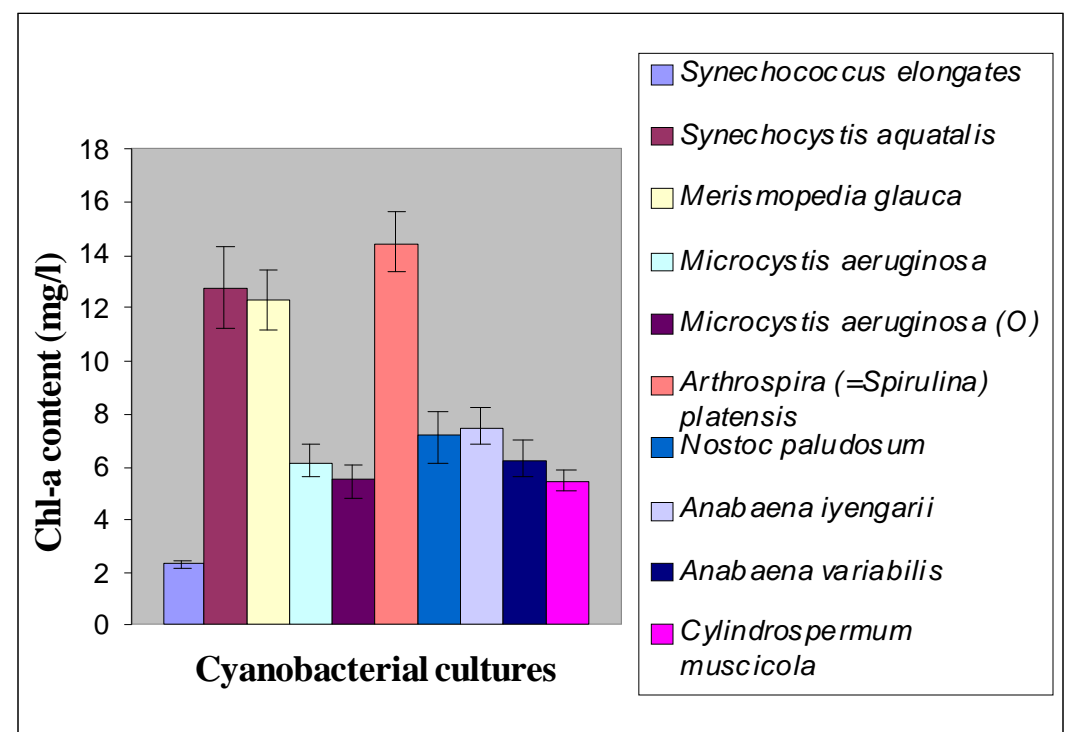

Fig. 3. Chl-a concentration in cyanobacterial cultures.

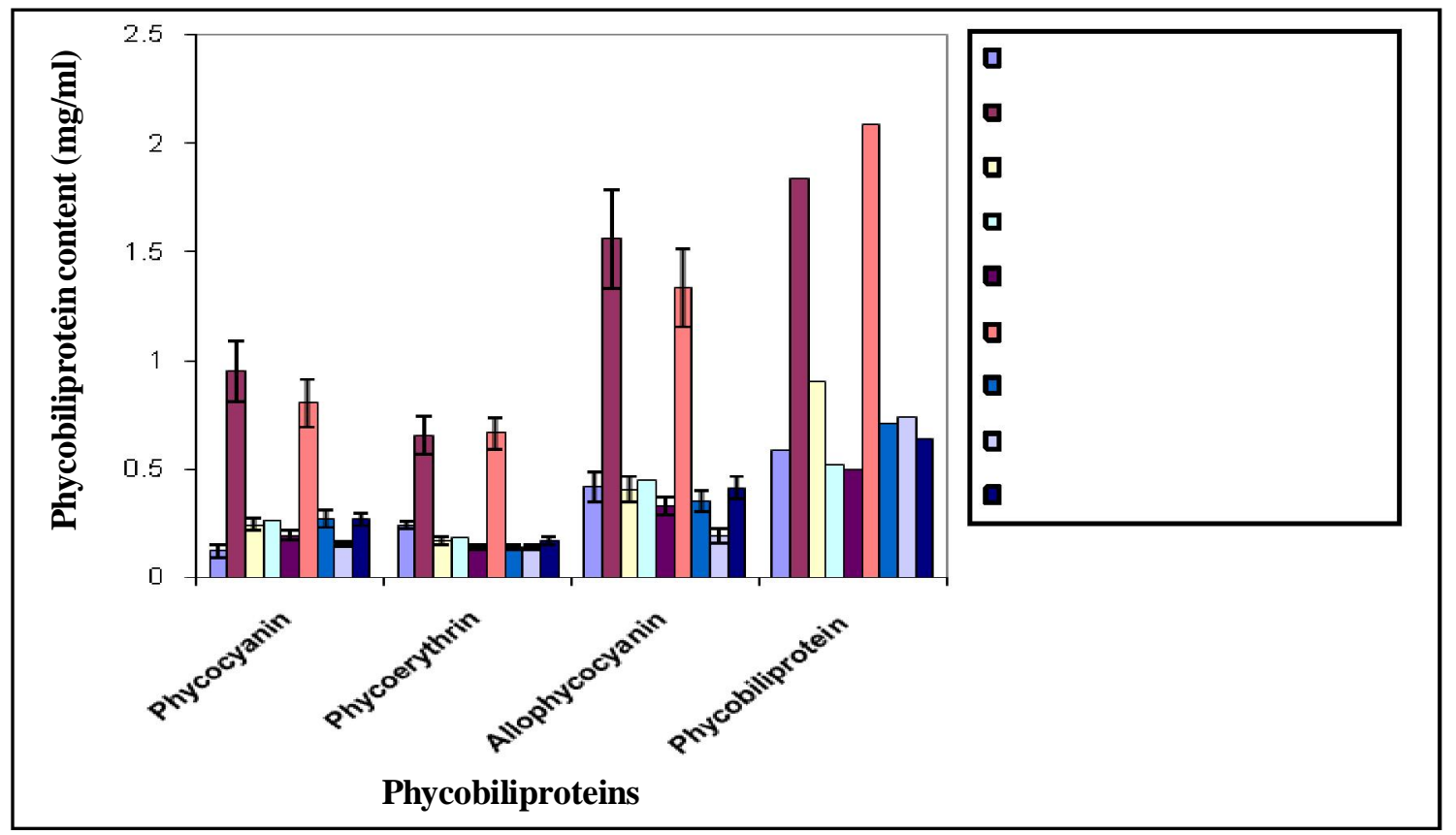

Fig.4. Phycobilipotein concentration in cyanobacterial cultures.

photosynthetic organisms, antioxidants are needed to adapt to changes in light, temperature and water potential as well as the anthropogenic stresses imposed by herbicides and pollutants. In Cyanobacteria, reports suggested indication of SOD, catalase or some peroxidases under conditions of oxidative stresses based on activity measurements (Mittler and Tel-Or, 1991; Abeliovich et al., 1974). The activity of antioxidative enzymes- Superoxide dismutase, Peroxidase catalase, and Ascorbate Peroxidase has also been reported from marine cyanobacterium 0. willei BDU 130511 (Saha et al., 2010). The enzymes involved in antioxidative activity and the cellular content of the antioxidants glutathione and ascorbate in the cyanobacteria N. muscorum 7119 and Synechococcus 6311 has been examined for their roles in hydroperoxide removal. High activities of ascorbate peroxidase and catalase were found in vegetative cells of both species and in the heterocysts of $\mathrm{N}$. muscorum (Tel-Or et al., 1986). Ascorbate peroxidase appears to be a key enzyme in a cascade of reactions regenerating antioxidants The direct mechanisms to recognize ROS or oxidative damages in cyanobacteria needs to be explored and the mechanisms behind the stability of these enzymes in various systems requires much elucidation .

\section{Conclusion}

Cyanobacteria possessed antioxidative enzymes to protect from reactive oxygen species. It was concluded that the antioxidative enzymes- catalase and Ascorbate Peroxidase played a vital role in toxic bloom forming 


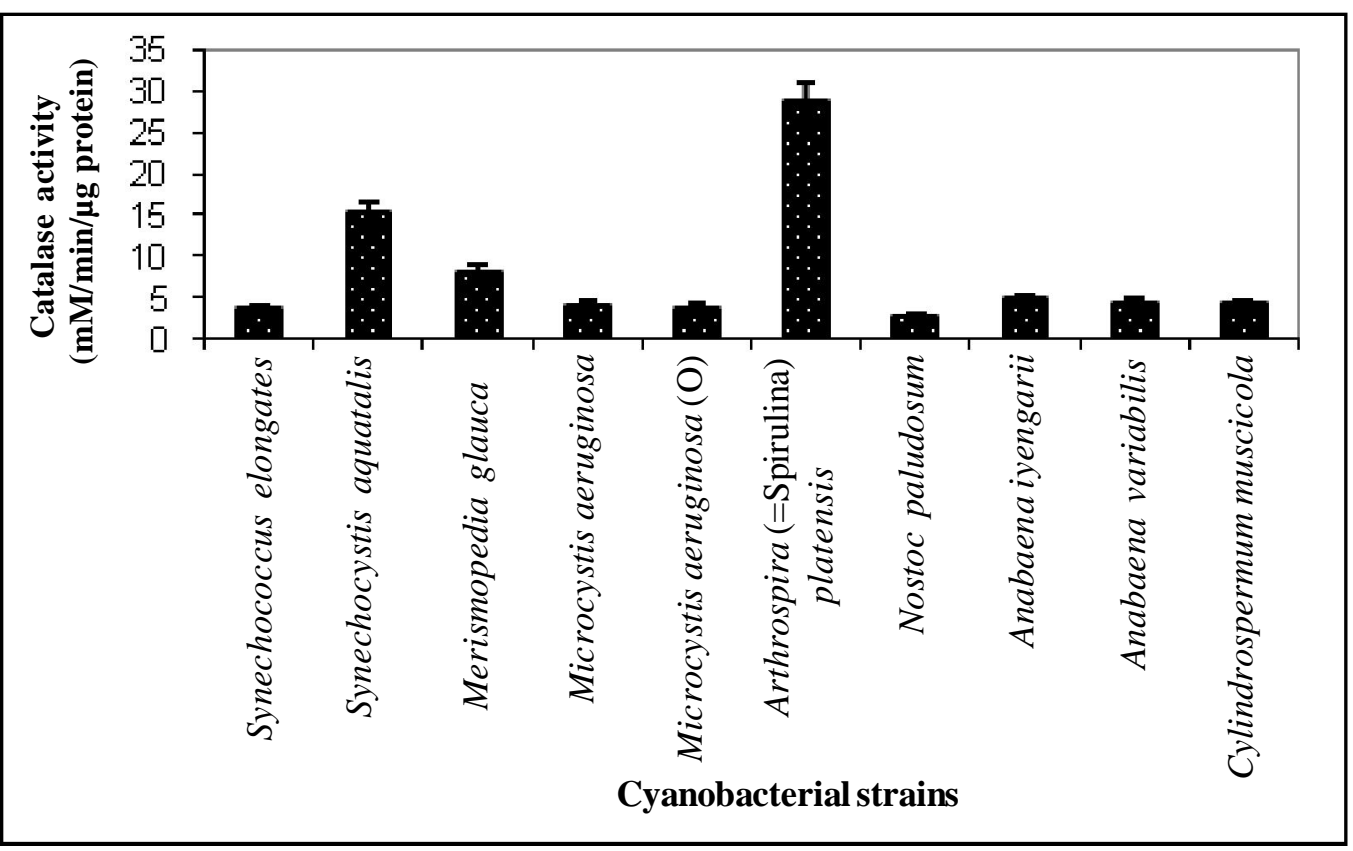

Fig.5. Activity of Catalase in cyanobacterial cultures.

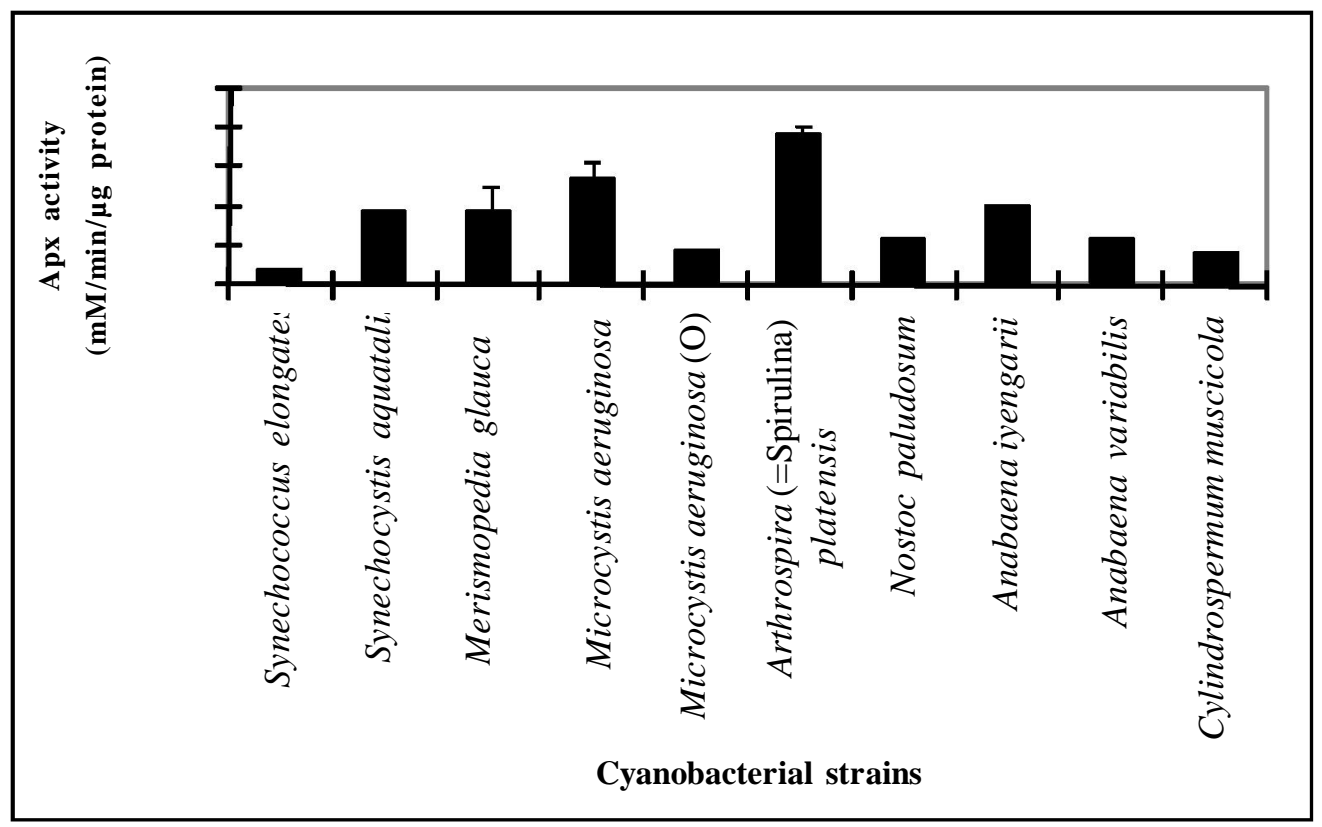

Fig.6. Activity of APX in cyanobacterial cultur es.

cyanobacteria. Cyanobacteria are easy to grow; pigments and enzymes can be extracted and employed for various purposes. The antioxidative of enzymes of cyanobacteria can be utilized in antioxidative therapy, processing and storage of food and other medicinally important preparations.

\section{REFERENCES}

Abeliovich, A., Kellenberg, D. and Shilo, M. (1974). Effect of photooxidative conditions on levels of superoxide dismutase in Anacystis nidulans. Photochem. Photobiol., 19: 379-282.

Asada, K. (1992). Ascorbate peroxidase: a hydrogen peroxide scavenging enzyme in plants. Physiol Plant, 85: 235-241.

Asada, K. (1997). The role of ascorbate peroxidase and monodehydroascorbate reductase in $\mathrm{H}_{2} \mathrm{O}_{2}$ scavenging in plants. In: Scandalios JG, ed. Oxidative stress and the molecular biology of antioxidant defences. Cold Spring Harbor Laboratory Press, 715-735.

Bennett, A. and Bogorad, L. (1971). Properties of subunits and aggregates of blue-green algal biliproteins. Biochemistry, 10: 3625-3634.

Bennett, A. and Bogorad, L. (1973). Complementary chromatic adaptation in a filamentous blue-green alga. J . Cell Biol., 58: 419-435.

Bradford, M. M. (1976). A rapid and sensitive method for the quantitation of microgram quantities of protein using the principle of protein-dye binding. Anal. Biochem., 72: 248-254.

Darr, D. and Fridovich, I. (1986). Irreversible inactivation of catalase by 3-amino-1, 2, 4-triazole. Biocheml Pharmacol., 
35 (20): 3642.

Fita, I. and Rossmann, M.G. (1985). The active center of catalase. J. M ol. Biol., 185 (1): 21-37.

Halliwell, B. and Gutteridge, J.M.C. (1999). Free Radicals in Biology and M edicine. 3rd ed. New York: Oxford University Press. pp: 134-140.

Minu Kesheri, Richa and Rajeshwar P. Sinha (2011). Antioxidants as natural arsenal against multiple stresses in cyanobacteria. International J ournal of Pharma and Bio Sciences, 2 (2): 168-187

Mittler, R. and Tel-Or, E. (1991). Oxidative stress responses and shock proteins in the unicellular cyanobacterium Synechococcus R2 (PCC 7942). Arch. Microbiol., 155: 125130.

Mittler, R. and Zilinkas, B.A. (1994). Regulation of Pea cytosolic ascorbate peroxidase and other antioxidant enzymes during the progression of drought stress and following recovery from drought. The Plant J ournal, 5: 397-405.

Miyake, C., Michihata, F. and Asada, K. (1991). Scavenging of hydrogen peroxide in prokaryotic and eukaryotic algae: acquisition of ascorbate peroxidase during the evolution of cyanobacteria. Plant and Cell Physiology, 32: 33-43.

Nakano, Y. and Asada, K. (1981). Hydrogen peroxide is scavenged by ascorbate-specific peroxidase in spinach chloroplasts. Plant and Cell Physiology, 22: 867-880.

Ohtake, A., Shrai, M., Aida, T., Mori, N., Harada, K., Kenji, M., Suzuki, M. and Nakano, M. (1989). Toxicity of microcystis species isolated from natural blooms and purification of the toxin. A ppl. E nviron. M icr obiol., 55: 32023207.

Pandey, A. (2007). Molecular and biochemical studies on bloom forming cyanobacteria, Ph.D. Thesis, University of Allahabad, India.

Porra, R. J., Thompson, W. A. and Kriedemann P. E. (1989). Determination of accurate extinction coefficients and simultaneous equations for assaying chlorophylls $\mathrm{a}$ and $\mathrm{b}$ extracted with four different solvents: verification of the concentration of chlorophyll standards by atomic absorption spectroscopy. Biochimica et Biophysica Acta, 975: 384-394.

Rao, M.V., Paliyath, G. and Ormrod, D.P. (1996). UltravioletB- and ozone-induced biochemical changes in antioxidant enzymes of Avabidopsis thaliana. Plant Physiol., 110: 125136.

Rippka, R. (1988). Isolation and purification of cyanobacteria. Methods Enzymol., 167: 3-27.

Rippka, R., Desruelles, J., Waterbury, J. B., Herdman, M. and Stanier, R. Y. (1979). Generic assignments, strain histories and properties of pure cultures of cyanobacteria. J ournal of General Microbiology, 111:1-61.

Saha, S.K., Swaminathan, P., Raghavan, C., Uma, L. and Subramanian, G. (2010). Ligninolytic and antioxidative enzymes of a marine cyanobacterium 0 scillatoria willei BDU 130511 during Poly R-478 decolourization. Bioresour Technol., 101(9):3076-84.

Scandalios, J.G. (1993). Oxygen stress and superoxide dismutases. Plant Physiol., 101: 7-12.

Shaaltiel Y. and Gressel J. (1986). Multienzyme oxygen radical detoxifying system correlated with paraquat resistance in Conyza bonaviensis. Pestic. Biochem. Physiol., 26: 22-28.

Sichak, S.P. and Dounce, A.L. (1986). Analysis of the peroxidatic mode of action of catalase. Archives of Biochem \& Biophys, 249 (2): 286-295.

Stanier R.Y., Kunisawa R., Mandel M. \& Cohen-Bazire G. (1971). Purification and properties of unicellular bluegreen algae (order Chroococcales). Bacteriological Reviews, 35: 171-205.

Tel-Or, E., Huflejt, M.E. and Packer, L. (1986). Hydroperoxide metabolism in cyanobacteria. Arch Biochem Biophys. 246 (1): 396-402.

Tel-Or, E., Huflejt, M.E. and Packer, L. (1985). The role of glutathione and ascorbate in hydroperoxide removal in cyanobacteria. Biochem.Biophys. Res. Commun., 132:533-539. 